\title{
Domestication Will Shape Future Public Spaces A Report from Rotterdam
}

\author{
Maurice Harteveld \\ Delft University of Technology, Netherlands \\ M.G.A.D.Harteveld@tudelft.nl
}

\begin{abstract}
This commentary aims to provide a window on the future by studying actions, taken to control the spreading of the corona virus, while obviously affecting public space over a year. What has been the effects on public space directly linked to these actions during the pandemic; what values play a role, and what can we expect for the future? We have seen how immediate responses induced by the COVID-19 crisis influences traveling, gathering, and public live in general. Now, it is time to look further. Having a base-point in Rotterdam and taking The Netherlands as an example, the commentary argues that some shifts in using, appropriating and experiencing public space will remain. Yet, mainly those not just being immediate responses to sudden societal change, rather those which are embedded in long-term change.*
\end{abstract}

Keywords: domestication, COVID-19, Rotterdam

* This articles includes research and statistics updated to March 202I.

To cite this article:

Harteveld, M. (2020). Domestication Will Shape Future Public Spaces. A Report from Rotterdam, The Journal of Public Space, 5(3), 53-66, DOI I0.3289I/jps.v5i3.I379

This article has been double blind peer reviewed and accepted for publication in The Journal of Public Space. (i) \$ This work is licensed under a Creative Commons Attribution - Non Commercial 4.0 International License https://creativecommons.org/licenses/by-nc/4.0/ 


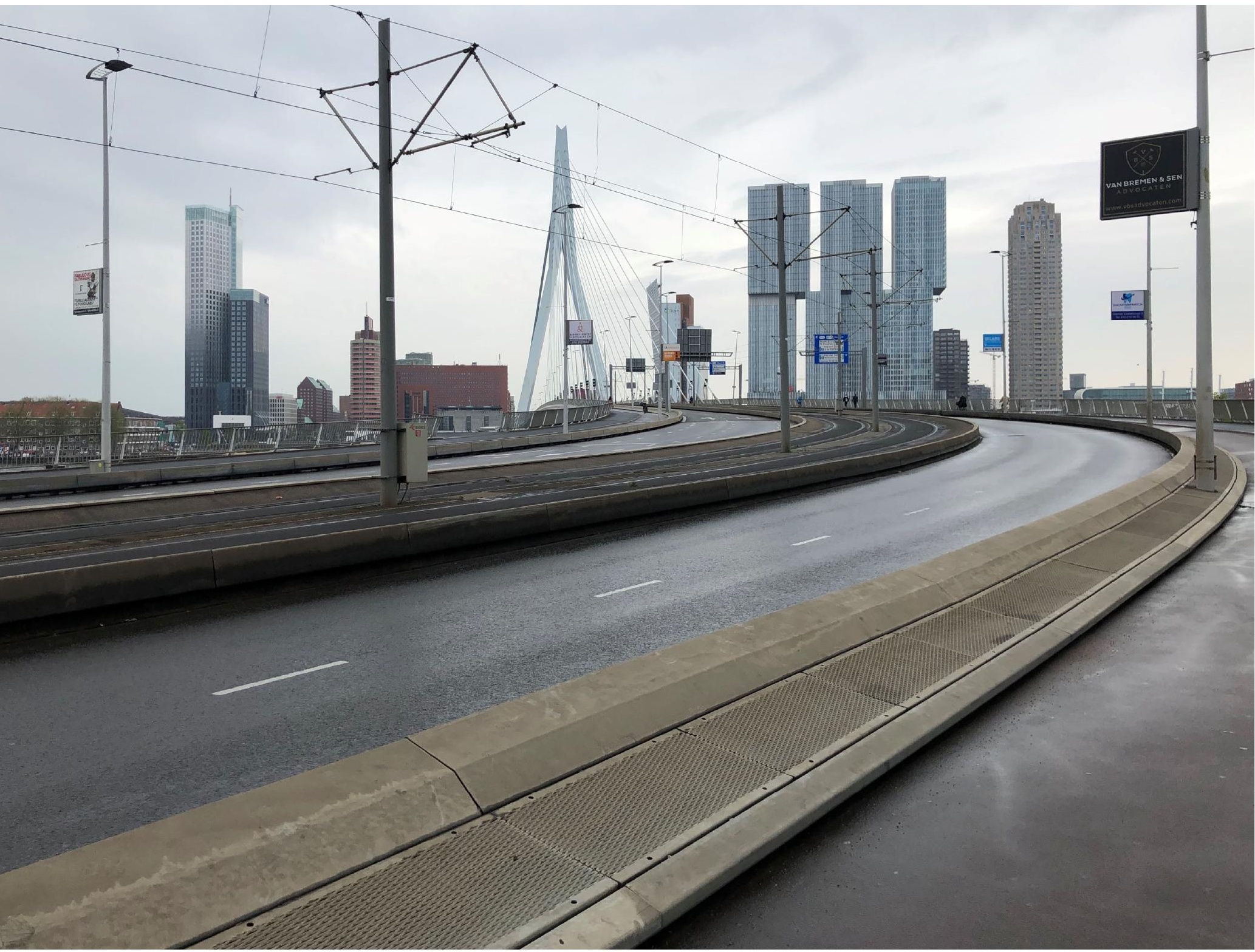

Figure I. Desolated Rotterdam, March 2020 (image by the author).

"In my daily work environment, at Delft University of Technology, almost all on-campus activities have been cancelled since Friday 13th of March 2020. De facto, the university buildings have been closed at that date, and academic life stayed alive online up to today! Small-scale education has been prioritised in specific periods and time-slots with respect to emergency ordinances and law. Occasionally I have met a colleague and graduate. Lectures and research meetings remain remote work. So, I have been on campus only $I \%$ of my working hours over a period of more than a year. As such, I am joining that part of society which is working from home because we can, and because we are asked to do so. The coronavirus influenced my work, profession, and discipline." 


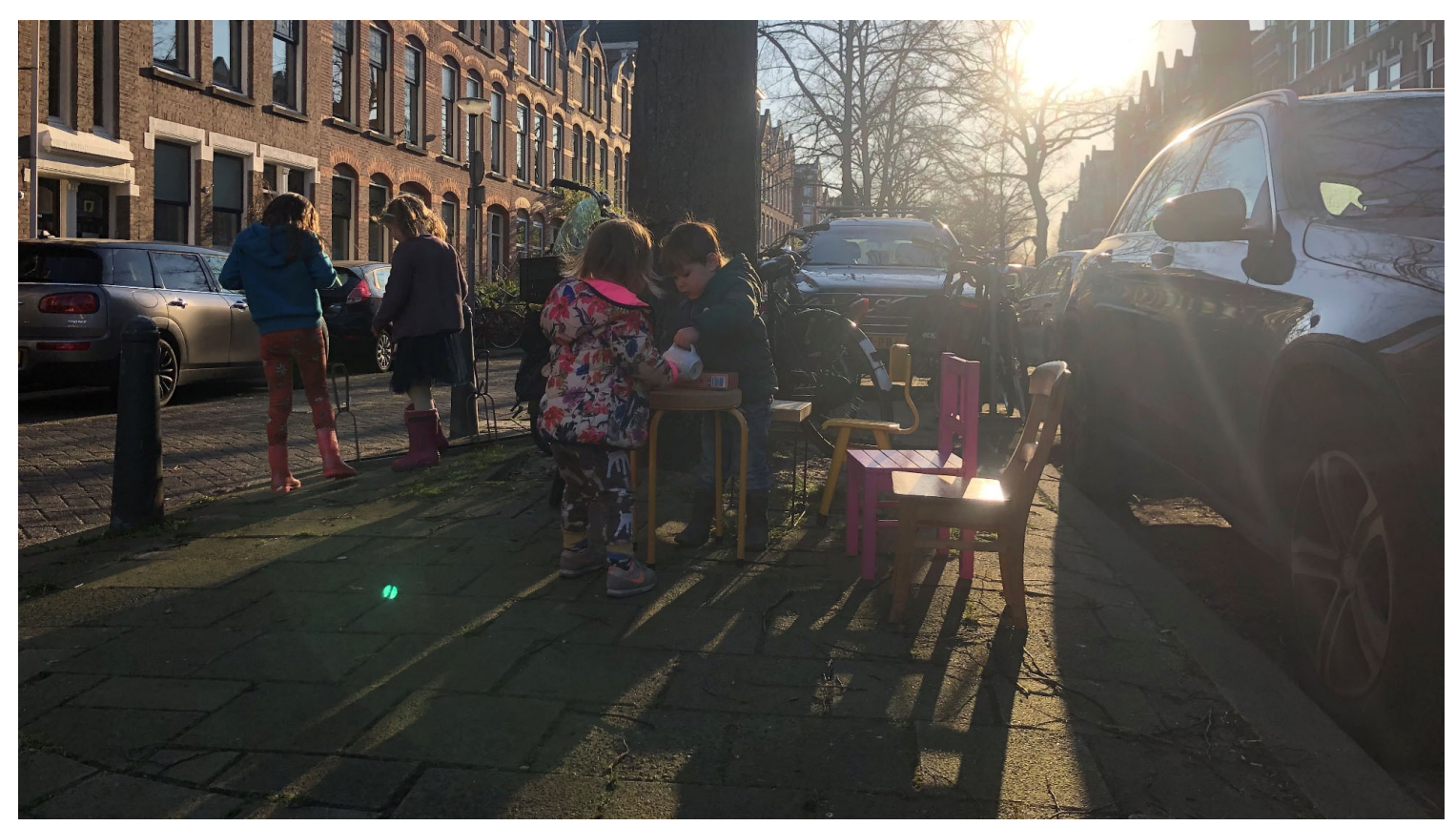

Figure 2. Domesticated Public Space, March 2020 (image by the author).

\section{COVID- 19: public measurements and effects in the public space}

The uninterrupted Dutch governmental calls upon people throughout the Netherlands to work from home as much as possible, or spread working hours, is illustrative for action effecting public space. Requests to avoid large group settings and public transport if not essential is adds to the impact on public space. Mirroring the initiation of farreaching containment measures taken in countries confronted with SARS-CoV-2 and the ongoing pandemic of COVID-19 in earlier stages, large meetings and events have even been cancelled throughout the country by ordinances. People do gather though, and go out, but not often crowding happens at large scale. Some moments, the police takes action. Sometimes access roads to parks or beaches have been controlled as acupuncture-like responses. Still, no enforced state of isolation, barricades, or nationwide control on movement. The size of outdoor meetings can only be within a range of four to two people, not from the same household, with an observable restricted I.5 metres between them. This rule is enforced only occasionally, when larger groups seem to provoke. A warning is more often applied. Public gatherings within interior public spaces have been restricted stronger than outdoors. Public buildings, like schools, childcare facilities, hotels, retail, restaurants, and cafes have been closed twice when reported hospitalised people have been at the high points.

Government urges people to limit visits to vulnerable people, with explicit restrictions to retirement and nursing homes. Furthermore, people with symptoms resembling a cold, having a cough, sore throat or fever are strongly requested to stay at home. (Government 2020, March 5; updated frequently) Effectively, people stayed home or close to home and seek alternatives for gathering. Generally, these effects seemed as desired. 


\section{Dynamic social values and acculturated global response landing in space}

The social consequences of such sets of measures are undoubtedly significant. They are worldwide. Health is a moral value which is shared globally. Consequently, public life has changed. This has been visible particularly in the Netherlands, because the Dutch are able to continue their lives in public uninterruptedly despite all. Police may monitor by air and by land, there is and has been no full lock-down. Without placing 17 million inhabitants and their foreign guests in quarantine, people share urgency for orders in still controllable situations. The Dutch government may have used power to delay the spread of the virus by all agreed legal means, but it exercises power foremost by calling upon social responsibility. Action is distributed. It's almost as if it echoes the Enlightened Dutch philosopher Baruch Spinoza: "obedience has no place in a social order where sovereignty is in the hands of everyone and laws are enacted by common consent". (see Harteveld 2019: 132) Dutch value 'free assembly' and 'connectivity'. The message going along with the first governmental actions contrasts for instance the French, which started with the presidential announcement that the government has taken firm action to curb the spread of the virus: "Nous sommes en guerre, en guerre sanitaire." (Macron 2020, 16 March) Such dissimilarities show how different countries are taking familiar measures reducing the spreading of the virus through different ways of acting. Socio-political consensus may differ, times of making decisions may, but foremost local cultures do. Contrasting authoritarian action, in the Netherlands, 'free will' somehow continues to be valued next to 'health'. People have been engaged to keep 'physical distancing', 'social abstinence', and 'public isolation' upon their own estimation. "So that our nursing homes, home care services, hospitals and, above all, our intensive care units don't become overwhelmed.", as Mark Rutte, the liberal Prime Minister of the Netherlands, emphasised on the immediate goal of the government in his first public address on the situation: reducing health risks by raising awareness to case fatality rates. At the same time, the long-term goal has been to build up herd immunity in a controlled manner, while waiting for a vaccine to be developed. "The reality is that coronavirus is here in our midst, and for the time being it is here to stay." (Rutte 2020, 16 March) Acceptance, as a person's assent to the reality, seems to come along for most people to mediate between values. Social values have been dynamic under pressure of moral believe to control health.

"When I look outside my window, I see a different world. That is to say, ...not fully unfamiliar. Full-grown lime trees dominate. In front of my house a free-assessable community garden demarcates a common place, surrounded by century-old urban building blocks. Neighbours gather outside. Kids play. In difference to say 2019, they do so more often, remaining on distance in a peaceful uncertainty every day. In addition, other locals keep enjoying the place. Different individuals and micro-groups are sitting down to meet, relax, read, eat, talk. Age, lifestyle, cultural background... many differences, mostly locals. In March, birds sang louder than ever. Tranquillity was periodically disturbed when pelotons of mostly male cyclists raced by. Public responsibility had not reached everybody! A police helicopter circled low above the space. Many more would follow. Once an animated group of vicenarians were sitting (too) close while enjoying a drink and making selfies. Another disruption? New hip place to be? Over spring, I've seen teenagers secretly kissing, as well as a frequent visiting elderly enjoying the sun during quiet hours with a mouth mask on. During summer, frequently my vogue neighbour of age shared dinner with her 'younger' friends. After they left in the Ramadan evenings, a guy in jellabiya met his casual friends to talk. At those days also the outdoor terrace of the next-door restaurant with 
tables on distance was always 'full'. When autumn started, more shared scooters appear. Eating take-out became the new norm at the place. Rain often prevented people to stay or take a stroll. In recent winter, neighbours went ice skating, teenagers-built snowmen, and parents pull their kids go to school on a sledge. This public space appeared to be a 'pars pro toto' for what was happening apparently throughout the country."
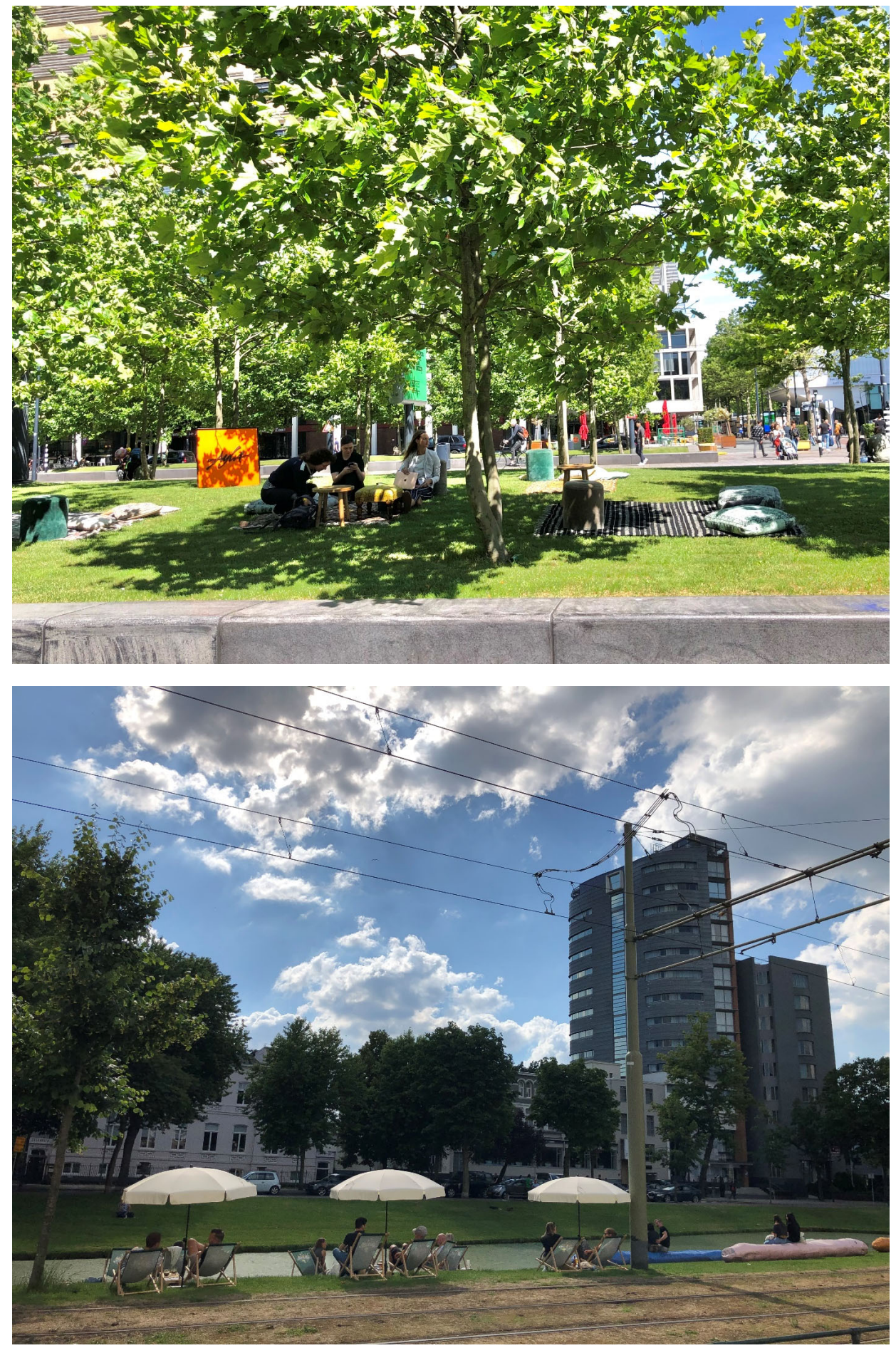

Figure 3. Urban living rooms, June 2020 (images by the author). 


\section{Behavioural Change in the Public Spaces}

Outdoors, the overall effect was manifest! Change in behaviour was observed immediately in the first weekend under the new conditions. People collaboratively shared in action. The public spaces were abandoned in March. Less people moved, there was hardly any traffic. Empty highways and alienated arterial roads! Sirens of ambulances and the sounds coppers of medical air rescue, increasing on daily base and only gradually diminishing after months, 'reminded us again that public life primary is affected by the health crisis. Immediate action introduced opposite effects at certain places too: The first kind came in the second weekend after the first public address. Weather was remarkably sunny. Quite some Dutch people flocked out naively. It was crowded in forests, parks and on the beaches. Keeping distance wasn't always possible anymore. The Dutch government quickly alerted citizens though their cell broadcast alarm system. The emergency notification read: “Keep your distance to others". (NL-Alert 2020, March 22) Since alarm bells rang, mass recreation largely stayed out. An additional public warning came: if crowding would appear again in these large public spaces, they would be closed. Prime Minister suggested: “...if there is no other option, choose a quiet place in your own neighbourhood: that small park that you normally skip, or the bench along the water." (Rutte 2020, 3 April) No need to effectuate closure. People sought alternatives and found these in hide-away public spaces already. In the following weekend, this generated a second kind of naive opposite effect. Neighbourhood places were found by outsiders, as friends were invited here. People also started running and cycling 'en masse', as sports facilities closed. There was significantly more traffic measured throughout the local urban fabric. (Bos and Rusman / De Voogt and Bolle 2020, 4 April) The national government also observer the pressure on these public spaces. Reacting on local crowding, the Prime Minister emphasised that major social dilemmas arose, which literally concern "the distribution of scarce space". Informed by medical advisors of the cabinet, he added an earlier forecast: "We will have to search together for the new normal in the one-and-a-half-meter society, a society that will be different in that respect from the way we were used to recently." (Rutte 2020, 7 and I5 April) The forecast echoed international prognoses. Although required distances might differ from state to state, depending culture and socio-spatial possibilities, the mantra became that the virus would stay thus physical distancing would determine our public lives, hence our public spaces. For a while a new comprising social value seemed to emerge: 'distancy'. It suited the short-term purpose. Yet, against the backcloth of this emergent apparent valuable property, undesired or at least unsought effects to this may have been more important signifiers for change: social values like 'togetherness' and 'commonness' translate in 'enjoying' leisurely green spaces in and around the city, and 'sharing' space near the house.

\section{Value Conflicts catalysing the (re-) Discovery of Local Life}

In the Netherlands, the level of basic rules, prevention measurements, and enforcing compliance were motivated by the stressed capacity of intensive care and grimly

\footnotetext{
' In 2020, nearly 22.5 thousand flights for police and trauma teams took off and landing in Rotterdam. (Schiedam-24 2021, I February)
} 
increasing death rates particularly during the first twelve weeks. ${ }^{2}$ People had not been tested at large scale nor consecutively at the time. Numbers turned to normal end of May. The majority of the population seemed healthy still/again. (RIVM 2020, May 2I; CBS 2020, May I5; and 202I, February 8) Easing of coronavirus restrictions started. Smaller group gatherings indoors/outdoors were accepted and, steadily controlled, all kinds of public buildings were allowed to open-up again, if only users take precautions following physical distancing rules and hygiene advices. It motivated large groups to visit beaches and parks again. Distance was pressured again. (Bouma 2020, May 22) People seemed not to be able to abolish crowding completely, or at least not endlessly. They embraced the popular new-found customs to go to the green areas. In addition, they complemented this with being outdoors in the neighbourhood. People actively (re)discovered the direct living environment. Since the COVID-19 crisis, numerous local initiatives have been set up. "People crave socialising", as a national Dutch newspaper observed; "This summer, areas in various cities will be made car-free to turn them into 'holiday streets' and 'living streets'." Citizen initiatives boomed. The sudden social revival in the residential area might be more than a temporary side-effect of the pandemic? "Corona forces many to look closer to home, and then it becomes more apparent what is missing there." (Van Noort 2020, 19 June) After this period without much restrictions, much less corona-deaths, ${ }^{3}$ and the introduction of intensive testing, nonetheless the second wave did start. Death rates peaked in October. Most long-term care recipients. ${ }^{4}$ (CBS 202I, February 8, RIVM 202I, March 13) Along with this news, people took a walk around the block even more often, or took the car to expand horizons. The city changed further despite release actions. Even inner-cities turned to the hustle and bustle for leisurely walks. Window-shopping was one of the alternative recreational forms that remained, next to experiencing green for example. Shops were open though and took into account public health measures and distance. Yet, walkers, not so much buyers, were dominating the shopping streets. The advance of this got an extra push in the first period. Webshops, including rising online versions of local stores and for example virtual fitting, provided alternatives. People found other ways to shop. (Leijten and Saris 2020, 27 April; Kamerman / Van den Dool and Wassens 2020, 26 October) Given the new peak, public life became under governmental control again, and in steps toward Christmas stricter measures were announced: "We all remember the news footage back in the spring. Empty motorways, empty trains and buses, empty offices and classrooms, empty shopping streets. That is the situation we have to return to", as the public address underlined. Coronavirus infection numbers grew: "The Netherlands is shutting down". Only shops selling basic necessities would stay open: supermarkets, shops selling food, including weekly markets, and chemists, dry cleaners, opticians and home care shops. In difference to March, all other stores were forced to close. Five weeks later, in $202 \mathrm{I}$, also the night-time curfew applied throughout the country. The increase of positive test results was made crucial in underpinning decisionmaking, as became distribution and infectivity models. (Rutte 2020, I4 December, and 2021, 23 February) The message had become stronger and governmental action

\footnotetext{
${ }^{2}$ In that period, 5,775 reported deaths confirmed to be caused by the coronavirus, with estimates being nearly double based on excess mortality. Ten thousand people seemed to have passed away.

${ }^{3}$ In the following four months: 690 confirmed corona-deaths.

${ }^{4}$ in October alone: 2,005 extra deaths. The second wave peaked lower, but lasted longer. Based on municipal reports, a total of 16,046 people died of COVID-19 in the Netherlands until March I3, 202 I.
} 
stricter, but the envisioned effect stayed out. Dutch cities did never return to be desolated anymore. Public life continued and evolved under the new condition.

"Saturday, I3th of March, $202 \mathrm{I}$. We are year later. Still on-distance online almost every day. I do observe a different world. It's not unfamiliar, but from a different angle. Outside my house, neighbours have remained the dominant user group: The local public. Birds sing less loud. They may be used to the reduced noise levels in the city. Citizens' initiatives may be small but manifest. Some garden benches are added to the sidewalk of my street. Street are being cleaned and plants watered by the people living around. Acceptance, little disobedience. Only one time, most recently, when a group sat around campfire after curfew, police on bikes intervened. Having less rules in perspective again, clusters do emerge more frequent than before though. Sunny weather is a stimulus, also during chilly days. I also go to urban forests, green parks and the beaches now. I see people everywhere. New are the trendy people with a coffee-to-go in Het Park of Rotterdam, and the urbanites - gold jacket and charcoal skinny jeans - with hot chocolate and take-away waffles in the woods of Kralingse Bos. One can't avoid the increase of outdoor athletes along the river Maas, and for example scooter girls and guys with a classic urban vibe and music in Zuiderpark. All such places are popular. Yet, different places, different groups. Regardless of closed shops, even the inner-city reveals a specific public. As I concluded last year; the city is our common house."

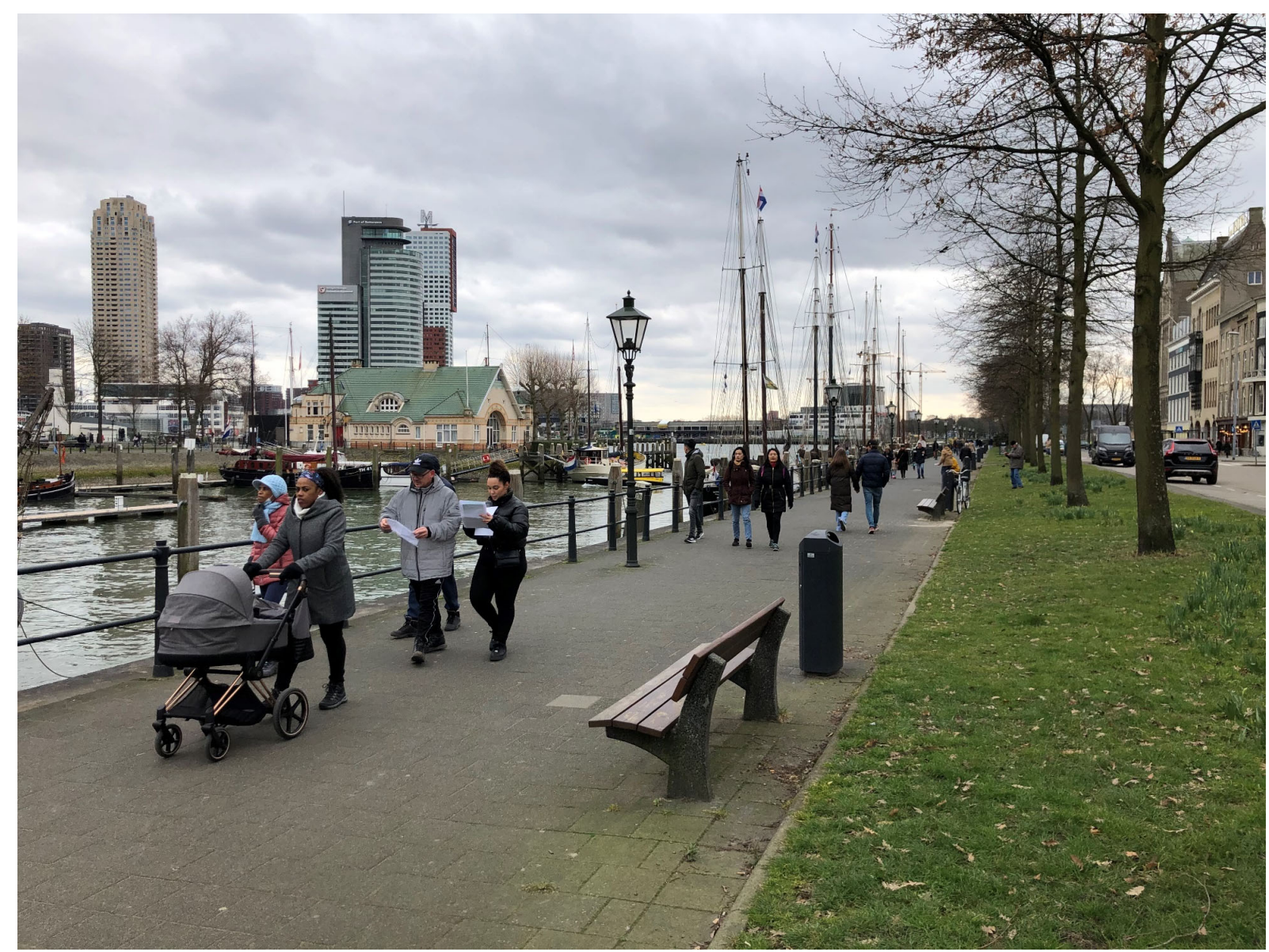

Figure 4. Different places, different people, March 202I (image by the author). 


\section{Living Together on the Long Term}

Recently, death rates has dropped becoming lower than normal. (CBS 202I, March 5) The development of a safe and effective vaccine for the highly communicable respiratory virus has always been an important epidemic control measure fitting the long-term goal. Interrupting chains of transmission nationwide remain simply the most effective action in this, until immunity has reached. (WHO 2020, 16-24 February) Vaccines have arrived and vaccination programmes are in process. The human coronaviruses is not disappearing overnight, but what about its impact on public spaces? What will stay in the future? All kind of scenarios have emerged over the past year. Futures embedded with full attention for urban hygiene and health follow prime moral value during the pandemic in its indisputably relevance around the world. There are also futures which are formed by trans-national calls to design for ongoing physical distancing, following the perspectives of virologist and epidemiologist. For sure, designers are able to alter the arrangement of public furniture in order to cater gatherings while withholding physical closeness, or to expand sidewalks, to parcel public space, and alike. Nonetheless, these solutions give short-term answers, valid until the virus is under control. Public life is evolving in a different direction though. Instead of physically distancing society, more likely, an opposite challenge will inform the design of public space on the long term. Not distancing but nearness seem to shape future public spaces. Localisation, social contraction, compression and convergence will balanced out globalisation, expansion, dispersion and divergence, even when human travel revives world-wide. The strong shift towards the house, as seen over the recent year, stays longer. People share public spaces in the neighbourhoods. More than ever! Different people, different places... Public spaces are not used by all people at once, nor by people as a whole: they never have been. The city is formalising our municipal autonomy in an anti-egoistic manner. The public interest is safeguarded. Health remains at stake. At the same time, public spaces are not only owned by governments representing the people. Not everything is controlled. Other actors and actions play a role too: Municipally-owned space is appropriated by all kinds of locals. Neighbourhood public spaces form the majority of public spaces. They are known by specific groups. (sec. Harteveld 2019: I38) In 2020, the public spaces close to home have come into scope explicitly, as did alternatives to temporary closed leisure, shopping, and entertainment spaces. People use, appropriate and experience their local environment, more than they did. Public space evolved into living rooms by/of/for people even further. The value of 'living together' is not changed. The quality of being together as a community is. This determines the future for the public space.

\section{Towards Designing Public Spaces for Domestication}

Of course not everybody is sticking to the house, and not always. Nowadays, no less than 3 million people, qualifying as crucial workers, are working anyhow on-site in The Netherlands. ${ }^{5}$ They have to move no matter what. (CBS 2020, 27 July) Also, we can state that others increasingly are travelling again since the first shock. Moving is inherent

\footnotetext{
${ }^{5}$ Here the term 'key occupations' applies: staff working in vital processes, care, social support, police, firefighters, crisis managers can't stay at home, like those taking care of fuel, waste, goods, information, and e.g. operating public transportation.
} 
to participating in life. Mobility is re-establishing despite stronger governmental measurements. Still, most important, comparing mobility patterns reveals that distance travel radically dropped over the year. (Google Analytics 2020, 29 March and 20 October; CBS 2021, 12 March) Hence, people stay local more than they did in 2019 and before. Strong ongoing economic and communication trends are pulling this shift for decades already. These determine the future of public space. From one standpoint, remote work and shopping are allowing certain people to stay home. (e.g. Baran and Greenberger 1967, Encel 1975, Salomon 1985, et seq.) In 2020, (partial) telecommuting just became very visible. ${ }^{6}$ So much as it became most prevalent among employees with certain occupations, like ICT professionals, managers, creatives, linguistics, teachers, administrators, and legal servants working. ${ }^{7}$ (CBS 2020, 6 April / 12 August, and 2021, 16 February) In 2020 too, online shopping and ordering clearly boosted, as prior to this, the rise has been already apparent. Over the recent decade, the number of physical stores has fallen consequently. People visit physical shops less. ${ }^{8}$ (CBS 2020, 4 August and 2019, 18 December; De Graaff 2004, Plaut and Shach-Pinsly 2019). From another standpoint, emerging economic and social distance to work and amenities keep people local. Travel costs and economic opportunities as well as travel time and communication barriers may keep people home, whereas increasing unemployment rates have always pushed the homeward shift. (e.g. Klaassen and Drewe 1973 et seq.) In 2020, significant groups have become financial victims of the coronavirus outbreak in the Netherlands. People have reduced workflow in the first two months and over time unemployment numbers have grown modestly, expected to grow more. Economic conditions remained fragile on the long term. ' (Jongen, Ebregt, Scheer, and von Gaudecker 2020, May; Adema, Yvonne, Wiljan van den Berge, and Alice Zulkarnain 2020, Augustus; and CPB 2020, November, and CBS 202I, I 8 February) Here, the offering of jobs and services in the vicinity of the house counts. Embedding last year's homeward shift in such pull and push factors, the strong estimate is that local, green and recreational public spaces effectively become more important in daily life anyhow. This may be supported by a third view point, one of the people themselves. When people are using and experiencing their direct living environment more, colliding a lack of alternatives, being more at home and/or having more free time, their general perspectives on public space change. We continue to exercise, stroll, sun, meet, or simply to be together - no matter of obeying physical distance. The expected increasing presence of locals at the neighbourhood scale supports an ongoing 'domestication of public space'. In this process, people accustom public spaces in the vicinity of their houses to make them fit for their changing lives related to being more at home. People are appropriating public space increasingly. Again, for over a decade, so-called proactive citizens aimed at the public interest, acting in the public domain, and so-called placemakers emerge. (e.g. Dekker, De Hart, and Faulk 2007, CROW, and Project for Public Spaces 2008). In 2020, new groups of people have become aware of the public

\footnotetext{
${ }^{6}$ During the first wave: 9 million people worked at home.

${ }^{7}$ Compared to statistics from before the outbreak: nearly twice as much ICT professionals worked home, exceeding $40 \%$ total. Also, a third of e.g. managers, creatives, linguistics, teachers, administrators did.

${ }^{8}$ Compared to a decade ago: II\% less shops and stores. In 2020: online sales increased by $3.9 \%$ in QI and $5.9 \%$ in $\mathrm{Q} 2$.

${ }^{9}$ In the first two months, about $13 \%$ of the working population reduced workflow and few became unemployed. Over 2020 , up to $3.6 \%$ of the labour population eventually did. For 2021 , the estimate is $6 \%$.
} 
spaces nearby. They take action together and recreate their shared public space. This does come with adjustments in public space and occasionally conflicts, like neighbour quarrels. (Sevil 2020, 27 September) It confirms that these people conceive public space as our valuable immediate living environment, and, within communities, they appropriate it progressively. Where possible bend it to their free will.

Ultimately, public space nearby becomes important. The urban space becomes an extension of the living room, even the urban living room itself. And, 'domestication' turns into a social value. The related shifts in using, appropriating and experiencing public space generate a wide variety of design assignments for the public space and the urban fabric. A strong call to design for all, including the equal provision of public space at local levels emerges. Different people, different places, thus different designs! This brings us closer together, ... once again! Something which ought to be familiar to public space.

\section{References}

Adema, Yvonne, Wiljan van den Berge, and Alice Zulkarnain (2020, August) Langdurige Effecten van de Coronacrisis voor de Arbeidsmarkt, CPB Coronapublicatie. Den Haag: Centraal Planbureau

Baran, Paul, and Martin Greenberger (1967, April) "Urban Node in the Information Network", P3562, Santa Monica: RAND Corporation, invited paper as presented at 1967 IEEE International Convention Record, March 20-23, Session 4, 'The City of Tomorrow', Monday 9:30 A.M. - 12:00 Noon, New York.

Bos, Kim and Floor Rusman (2020, 4 April) "Social Distancing. Corona: Garantie op Groot Social Ongemak", NRC Weekend, Zaterdag 4 \& Zondag 5 April, 2020, pp. 2-3

Bouma, Katja (2020, 22 May) "Raportage: Drukte in Amsterdam. Naar Buiten, Ja. Wat moet je Anders?” De Volkskrant, Vrijdag 22 Mei 2020, pp.2-3

CBS (2019, I8 December) In Tien Jaar Tijd Ruim II Procent Minder Winkels, I 8-I 2-2019 00:00, https://www.cbs.nl/nl-nl/nieuws/2019/5 I/in-tien-jaar-tijd-ruim- I I-procent-minder-winkels, retrieved 20 November 2020

CBS (2020, 6 April) Thuiswerkers per Beroep, 2019, 6-4-2020 12:00, as published at https://www.cbs.nl/nl-nl/maatwerk/2020/I5/thuiswerkers-per-beroep-2019, retrieved 2 March 2020

CBS (2020, I5 May) Nearly 9 Thousand More Deaths in First 9 Weeks of COVID-19, 15-5-2020 15:01, as published at https://www.cbs.nl/en-gb/news/2020/20/nearly-9-thousand-moredeaths-in-first-9-weeks-of-covid-19, retrieved 20 May 2020

CBS (2020, 22 May) Deaths registered Weekly, by Sex and Age. Changed on: 22 May 2020, published at https://opendata.cbs.nl/statline/\#/CBS/en/dataset/70895ENG/table?ts=I590076257433

CBS (2020, 27 July) Hoeveel Mensen werken er in Cruciale Beroepen? (incl. Bijlage Revisieberoepen Tabell en Tabel2, 27/7/2020), as published at https://www.cbs.nl/nlnl/faq/corona/economie/hoeveel-mensen-werken-er-in-cruciale-beroepen-, retrieved I March 2020

CBS (2020, 4 August) Coronacrisis jaagt Online Winkelen aan in het Tweede Kwartaal, 4-8-2020 00:00, as published at https://www.cbs.nl/nl-nl/nieuws/2020/32/coronacrisis-jaagt-onlinewinkelen-aan-in-het-tweede-kwartaal, retrieved 20 November 2020 
CBS (2020, 12 August) ICT Workers at Home most often during Coronavirus Crisis, I2-8-2020 15:00, as published at https://www.cbs.nl/en-gb/news/2020/33/ict-workers-at-home-mostoften-during-coronavirus-crisis, retrieved 20 November 2020

CBS (202I, 8 February) Nearly 13 thousand COVID-1 9 Deaths up to November 2020, 8-2-202I 15:00, as published at https://www.cbs.nl/en-gb/news/2021/05/nearly-13-thousand-covid-19deaths-up-to-november-2020, retrieved I March 2020

CBS (202I, I6 February) Werkzame Beroepsbevolking; Thuiswerken, I6-2-202I 02:00, as published at https://www.cbs.nl/nl-nl/cijfers/detail/83258NED?q=thuiswerkers, retrieved 3 March 2020

CBS (202I, I8 February) Werkloosheid gedaald naar 3,6 Procent, I8-2-202I 06:30, as published at https://www.cbs.nl/nl-nl/nieuws/2021/07/werkloosheid-gedaald-naar-3-6-procent, retrieved I March 2020

CBS (202I, 5 March) Mortality in Week 8 lower than expected, 5-3-202। 15:00, as published at https://www.cbs.nl/en-gb/news/2021/09/mortality-in-week-8-lower-than-expected, retrieved I March 2020

CBS (202I, 26 February) Detailhandel; Omzetontwikkeling, Index 2015=100. Gewijzigd op: 26 februari 2021 , as published at https://opendata.cbs.nl/\#/CBS/nl/dataset/83868NED/table?ts=|615823425053, retrieved I March 2020

CBS (202 I, 12 March) Mobiliteit in Coronatijd, I2-3-202 I 10:04, as published at https://www.cbs.nl/nl-nl/visualisaties/welvaart-in-coronatijd/mobiliteit, retrieved I 3 March 2020

CPB (2020, November) Novemberraming: Economische Vooruitzichten 202 I, CPB Raming. Den Haag: Centraal Planbureau, retrieved from https://www.cpb.nl/raming-november-2020vooruitzicht-202I

CROW, and Project for Public Spaces (2008) Succesvolle Openbare Ruimtes: Praktijkvoorbeelden en Principes. (Publicatie 273). Ede: CROW, 2008

De Graaff, Thomas (2004). On the Substitution and Complementarity between Telework and Travel: A Review and Application. (paper presented at the NECTAR workshop 'Communication, Labour Markets and Urban Systems' organized at the University of Alicante). Amsterdam: Vrije Universiteit Amsterdam, retrieved from http://degree.ubvu.vu.nl/repec/vua/wpaper/pdf/200400I6.pdf

De Voogt, Sam, and Joram Bolle (2020, 4 April) "Vaker de Weg op. Buitensport. De Rondjes zijn niet meer te tellen", NRC Weekend, Zaterdag 4 \& Zondag 5 April, 2020, PP. E2I-E23

Dekker, Paul, Joep de Hart, and Laila Faulk (2007) Toekomstverkenning Vrijwillige Inzet 2015. Den Haag: Sociaal en Cultureel Planbureau 
Encel, S (1975, October) "Social Aspects of Communication", invited paper, IEEE Transactions on Communications, Vol. COM-23, No. 10, October 1975, pp. 1012-1018

Google Analytics (2020, 29 March) COVID-19 Community Mobility Reports on The Netherlands, available at https://google.com/covid I/mobility

Google Analytics (2020, 20 October) COVID-1 9 Community Mobility Reports on The Netherlands, available at https://google.com/covid I9/mobility

Government (2020, 5 March) Dutch Measures against Coronavirus. online since March 5th, 2020, and frequently updated: https://www.government.nl/topics/coronavirus-covid-I9/tacklingnew-coronavirus-in-the-netherlands

Harteveld, Maurice (2019) "Reviewing Premises on Public Spaces in Democratic, Inclusive, Agential Cities, Illustrated by Amsterdam", The Journal of Public Space, 4(2), pp. I23- I 44.

Jongen, Egbert, Jos Ebregt, Bas Scheer, and Hans-Martin von Gaudecker (2020, May) Arbeidsmarkt: Sterke Daling Gewerkte Uren. CPB Coronapublicatie. Den Haag: Centraal Planbureau.

Kamerman, Sheila (2020, 26 October) "Winkelen in Coronatijd: 'We nemen het er nog even van", NRC Handelsblad, Maandag 26 Oktober 2020, pp. 6-7.

Klaassen, Leo Hendrik, and Paul Drewe (1973) Migration Policy in Europe : A Comparative Study. Farnborough: Saxon House / Lexington: Lexington Books.

NL-Alert (2020, 22 March) Noodmelding NL-Alert 22-03-2020 I I :29 "Volg Instructies Rijksoverheid op: houd I,5 Meter Afstand! Bent u Ziek of Verkouden? Blijf Thuis. Bescherm Uzelf en de Mensen om u heen. Samen tegen Corona. Keep your Distance to Others."

NRC (2020, 2I May) "Drukte op Hemelvaartsdag", as published online only at https://www.nrc.nl/nieuws/2020/05/21/drukte-op-hemelvaartsdag-a4000432

Macron, Emmanuel (2020, 16 March) Adresse aux Français du Président de la République Emmanuel Macron, 16 Mars 2020. Paris: Élysée

Plaut, Pnina O. and Dalit Shach-Pinsly (2019) Digital Social Networks and Travel Behaviour in Urban Environments. London and New York: Routledge

RIVM (2020, May 21) COVID- 19: Current Information, as published at https://www.rivm.nl/en/novel-coronavirus-covid-19/current-information-about-novelcoronavirus-covid-19, retrieved 2I May 2020

RIVM (202I, March I3) "COVID-19_Aantallen_Gemeente_Cumulatief.csv" (this file contains the cumulative numbers of positively tested persons and the number of hospital admissions per reporting date, and the number of deaths per death date, per municipality in The Netherlands), daily updated and published at: https://data.rivm.nl/covid-I9/COVID19 aantallen_gemeente_cumulatief.csv, retrieved 21 May 2020

Rutte, Mark (2020, 16 March) Television Address by Prime Minister Mark Rutte of the Netherlands, as translated at https://www.government.nl/documents/speeches/2020/03/16/televisionaddress-by-prime-minister-mark-rutte-of-the-netherlands, retrieved 20 May 2020. 
Rutte, Mark (2020, 3 April) Letterlijke Tekst Persconferentie na Ministerraad 3 april 2020. Mediatekst |03-04-2020. retrieved 20 May 2020 at https://www.rijksoverheid.nl/documenten/mediateksten/2020/04/03/letterlijke-tekstpersconferentie-na-ministerraad-3-april-2020

Rutte, Mark (2020, 7 April) Letterlijke Tekst Persconferentie Minister-President Rutte en minister De Jonge na afloop van crisisberaad cabinet. Mediatekst | 07-04-2020, retrieved 20 May 2020 at https://www.rijksoverheid.nl/documenten/mediateksten/2020/04/07/letterlijke-tekstpersconferentie-minister-president-rutte-en-minister-de-jonge-na-afloop-van-crisisberaadkabinet

Rutte, Mark (2020, 7 April) Letterlijke Tekst Persconferentie Minister-President Rutte en minister De Jonge na afloop van crisisberaad cabinet. Mediatekst | 15-04-2020, retrieved 20 May 2020 at https://www.rijksoverheid.nl/documenten/mediateksten/2020/04/I5/letterlijke-tekstpersconferentie-minister-president-rutte-en-minister-de-jonge-na-afloop-van-crisisberaadkabinet

Rutte, Mark (2020, I4 December) Television address by Prime Minister Mark Rutte of the Netherlands, as translated at https://www.government.nl/documents/speeches/2020/I2/ /4/television-address-by-primeminister-mark-rutte-of-the-netherlands, retrieved I March 202I.

Rutte, Mark (202I, 23 February) Letterlijke tekst persconferentie minister-president Rutte en minister De Jonge, Mediatekst | 23-02-202I, retrieved 2 March 202 I at https://www.rijksoverheid.nl/documenten/mediateksten/2021/02/23/letterlijke-tekstpersconferentie-minister-president-rutte-en-minister-de-jonge-23-februari-202I

Schiedam-24 (202I, I February) Bijna Zeventig Procent minder Verkeer op Vliegveld Rotterdam, 01 02-202I, retrieved I March 202I at https://schiedam24.nl/nl/nieuws/nieuws/bijna-zeventigprocent-minder-verkeer-op-vliegveld-rotterdam/1645I

Sevil, Malika (2020, 27 September) "Achtergrond: In Coronatijd ergeren Buren zich Helemaal Groen en Geel”, Het Parool, Zaterdag, 26 September 2020, pp. I, and 6

Salomon, Ilan (1985, September) "Telecommunications and Travel: Substitution or Modified Mobility?” Journal of Transport Economics and Policy, Sep., 1985, Vol. 19, No. 3, pp. 219235

Van den Dool Pim, and Rik Wassens (2020, 26 October) "In De Tweede Golf Gaan We Weer Wat Vaker Even Een Blokje Om”, NRC Handelsblad, Maandag 26 Oktober 2020, pp. 6

Van Noort, Wouter (2020, 19 June) "Hé wat Leuk, De Buren! Hoe in Coronatijd Mensen hun Eigen Wijk Ontdekken”, NRC Cultuur: Leven. De Buurt bloeit op. A section of NRC Handelsblad, Maandag 22 Juni 2020.

WHO (2020, 16-24 February) Report of the WHO-China Joint Mission on Coronavirus Disease 2019 (COVID-19). Geneva: World Health Organization (WHO). 